DOI https://doi.org/10.30525/978-9934-26-040-7-40

\title{
ПРОБЛЕМНІ АСПЕКТИ ВПРОВАДЖЕННЯ ТЕЛЕМЕДИЦИНИ В УКРАЇНІ
}

\author{
Корлюк C. C. \\ студентка I курсу магістратури \\ Iнституту права
}

Київського національного університету імені Тараса Шевченка

м. Київ, Украӥна

У період пандемії COVID-19 особливо гостро постало питання надання якісних медичних послуг безпечним шляхом. У цій ситуації на допомогу приходить телемедицина, що останні роки активно впроваджується в Україні. Згідно з визначенням Всесвітньої Організації Охорони Здоров'я, телемедицина - метод надання послуг із медичного обслуговування там, де відстань $\epsilon$ критичним чинником. Телемедичні послуги визначаються законодавством як комплекс дій, технологій та заходів, що застосовуються під час надання медичної допомоги 3 використанням засобів дистанційного зв'язку для обміну інформацією в електронній формі [1].

Дослідженням особливостей телемедицини та іiі ролі у системі охорони здоров'я займаються такі науковці, як $\mathrm{X}$. Терешко, А. Щербіна, К. Римаренко, Н. Філіппова, та інші.

Метою дослідження є розгляд проблемних аспектів телемедицини на сучасному етапі пї розвитку в Україні.

Телемедицина дозволяє пацієнту звернутися до потрібного йому спеціаліста за короткий час та отримати вичерпну консультацію щодо стану свого здоров'я за допомогою інформаційно-комунікаційних технологій, незалежно від місця перебування сторін. Так, підвищення доступності та якості медичного обслуговування у сільській місцевості $\epsilon$ одним із пріоритетних напрямів державної політики у сферах охорони здоров'я та регіонального розвитку [2].

Цифровізація результатів обстеження дозволяє своєчасно і без втрати змісту передавати інформацію про пацієнта між лікарями та медичними закладами. Оперативне звернення до лікаря також може запобігти критичним станам. Так, відповідно до статистики Міністерства охорони здоров'я України, лікарі у Вінницькій області виявили на $60 \%$ більше випадків гострого інфаркту міокарда завдяки впровадженню технологій телемедицини [3]. Превентивна медицина 
дозволяє рятувати життя пацієнтів та економити державні кошти, що витратилися $б$ на тривале лікування пацієнтів 3 ускладненнями. Особливо гостро постає потреба у наданні медичних послуг за допомогою мережі Інтернет під час карантину, коли соціальне дистанціювання $\epsilon$ пріоритетним. Телемедицина - це також надання дистанційних консультацій з використанням мобільного обладнання, 3 яким фельдшер може виїхати додому до пацієнта та виміряти основні показники здоров'я і у режимі реального часу передати відповідному спеціалісту за допомогою інформаційно-комунікаційних технологій для постановки діагнозу.

Отже, розвиток телемедицини як складової е-медицини, на сьогодні $\epsilon$ важливим напрямом державної політики у медичній сфері. Однак існують певні складнощі у впровадженні телемедицини, які можна класифікувати залежно від сфери їх виникнення:

- У сфері правового регулювання ;

На сьогодні можна констатувати активний розвиток законодавства у сфері телемедицини, однак $є$ певна хаотичність щодо запровадження норм, стандартів, уніфікацій форм статистичної звітності у цій галузі [4]. На думку автора, доречним $\epsilon$ прийняття єдиного нормативного акта, що регулював би відносини щодо надання дистанційних медичних послуг.

- У сфері технічного забезпечення ;

Телемедичні послуги потребують технічних та інформаційнопрограмних засобів, зокрема, відповідне програмне i програмноапаратне забезпечення порталу телемедицини, засобів зв'язку, тощо. Пріоритетним напрямом підвищення доступності та якості медичного обслуговування має бути сприяння забезпечення зазначеними технічними засобами лікувальних закладів усіх форм власності, центрів первинної медичної (медико-санітарної) допомоги, та матеріальнотехнічної бази таких закладів, створення умов для діяльності лікарів загальної практики - сімейних лікарів та лікарів інших спеціальностей, які надають медичну допомогу, адже до сьогодні не усі лікарі мають у розпорядженні персональний комп'ютер з доступом у мережу Інтернет.

- У сфері інформаційної безпеки ;

У процесі надання телемедичних послуг лікарі та обслуговуючий персонал медичної інформаційної системи оперує чутливими персональними даними пацієнтів, за таких умов $є$ необхідність забезпечення збереження конфіденційних даних та лікарської таємниці. Забезпечення інформаційної безпеки здійснюється перш за все шляхом управління доступом до платформ, через які надаються телемедичні послуги, що включає ідентифікацію користувачів, встановлення автентичності об’єкта або суб'єкта, перевірку повноважень, протоколювання 
звернень до ресурсів, що захищаються, тощо [5]. Нехтування регламентами безпеки та економія на розробці якісної архітектури інформаційних систем спричинятиме витоки інформації з обмеженим доступом, що завдаватиме матеріальних й репутаційних збитків користувачам цих систем.

- У сфері фінансового забезпечення.

Якісне технічне обладнання, залучення спеціалістів для роботи 3 інформаційною системою, навчання персоналу та просвітницька діяльність для ознайомлення громадян 3 таким способом надання медичних послуг потребують значних витрат. Тут варто зауважити, що в перспективі, телемедицина зможе заощадити витрати на медичне обслуговування, завдяки запобіганню розвитку ускладнень у пацієнтів.

Таким чином, телемедицина $є$ тим механізмом, що робить медичні послуги доступнішими для громадян, незалежно від їх місця проживання. Введення карантину у зв'язку з COVID-19 дало поштовх розвитку телемедицини у нашій державі, що супроводжується окресленими проблемними аспектами, які можна вирішити системним підходом до регулювання телемедичних послуг. Зокрема, автор притримується думки, що є потреба уніфікувати відносини у сфері телемедицини шляхом прийняття єдиного нормативного акта.

\section{Література:}

1. Основи законодавства України про охорону здоров'я: Закон України від 19 листопада 1992 року 2801-XII/ Верховна Рада України. URL: https://zakon.rada.gov.ua/laws/show/2801-12\#Text (дата звернення: 23.02.2021).

2. Про підвищення доступності та якості медичного обслуговування у сільській місцевості: Закон України від 14 листопада 2017 року № 2206-VIII/Верховна Рада України. URL: https://zakon.rada.gov.ua/ laws/show/2206-19\#Техt (дата звернення: 23.02.2021).

3. Завдяки телемедицині на Вінниччині виявили на $60 \%$ більше випадків гострого інфаркту URL: https://moz.gov.ua/article/news/ zavdjaki-telemedicini-na-vinnichchini-vijavili-na-60-bilshe-vipadkivgostrogo-infarktu (дата звернення: 23.02.2021).

4. Назірова Т. О., Костенко О. Б. Огляд моделей розвитку eHealth та наявних медичних інформаційних систем. Проблеми створення єдиного медико-інформаційного простору. Науковий вісник НЛТУ України. 2017. Вип. 27(10). С. 151-155.

5. Гулька О. О. Алгоритми захисту персональних даних пацієнта в телемедицині / Algorithms for patient data protecting in telemedicine / Гулька Олександр Олександрович - Тернопіль, 2019. С. 25-26. 